\title{
Crude glycerin inclusion in Santa Inês ewes' diet before and during the breeding season: its effects on physiological parameters, hematological variables, and reproductive performance
}

\section{Inclusão de glicerina bruta na dieta de ovelhas Santa Inês antes e durante a estação de monta: Seus efeitos nos parâmetros fisiológicos, variáveis hematológicas e desempenho reprodutivo}

\author{
Marta Maria Soares de Freitas Almeida ${ }^{1}$; Marcos Jácome de Araújo ${ }^{1}$; \\ Jacira Neves da Costa Torreão ${ }^{2}$; Carlo Aldrovandi Torreão Marques ${ }^{3}$; \\ Andressa Francisca Silva Nogueira ${ }^{1}$; Everton Almeida Pereira ${ }^{1}$; \\ Tãnia Vasconcelos Cavalcante ${ }^{4}$;Tairon Pannunzio Dias-Silva ${ }^{5 *}$; Veerasamy Sejian ${ }^{6}$
}

\section{Highlights:}

Impact of crude glycerin (CG) on physiological and reproductive performance.

All ewes exhibited estrus during the breeding season.

CG did not drastically change the hematological and biochemical variables.

CG can be used up to $10 \%$ in replacement of ground corn.

\begin{abstract}
In this study, we aimed to evaluate the effect of concentrate supplementation containing crude glycerin (CG) before and during the breeding season on the physiological and blood biochemical variables as well as on the reproductive performance of Santa Inês ewes. A total of 24 ewes (12 pluriparous and 12 nulliparous ewes, 4 and 1.5 years old, weighing an average of $40 \pm 5$ and $27 \pm 3 \mathrm{~kg}$, respectively) were randomly assigned to three treatments consisting of different dietary concentrations of $\mathrm{CG}(0 \%, 5 \%$, and $10 \%$ of the total dry matter). The experiment lasted 63 days and was divided into three 21 -day phases. In the first and second phases, the animals were subjected to flushing. In the second and third phases, we evaluated the animals' reproductive performance. Weather, physiological, and blood biochemical variables were also studied. The results indicated that the inclusion of CG did not influence significantly $(P>0.05)$ either the ewes' body weight or their body condition score. All ewes exhibited estrus during the breeding season. Their respiratory rate was significantly influenced by the time of day $(P<0.0001)$. A $10 \%$ CG supplementation did not drastically change the hematological and biochemical variables, which were within the reference ranges. However, the week of supplementation influenced serum
\end{abstract}

\footnotetext{
1 Profs., Programa de Pós-Graduação em Zootecnia, Universidade Federal do Piauí, UFPI, Campus Professora Cinobelina Elvas, Bom Jesus, PI, Brasil. E-mail: marta.strela@hotmail.com; jacome@ufpi.edu.br; dessafsn@yahoo.com.br; evertonap@hotmail. com

2 Prof ${ }^{a}$, Instituto Federal de Sergipe, IFS, Aracaju, SE, Brasil. E-mail: jacira.torreao@ufpi.br

3 Prof., Departamento de Zootecnia, Universidade Federal de Sergipe, UFS, Nossa Senhora da Gloria, Sergipe, SE, Brasil. E-mail: cjtorreao@yahoo.com.br

4 Profa, Programa de Pós-Graduação em Ciência Animal, UFPI, Campus Professora Socopo, Teresina, PI, Brasil. E-mail: tania@ ufpi.edu.br

5 Prof., Instituto Federal do Amazonas, IFAM, Campus Maués, AM, Brasil. E-mail: tairon.mvet@gmail.com

6 Prof $^{\mathrm{a}}$, Division of Animal Physiology, ICAR-National Institute of Animal Nutrition and Physiology NIANP, Adugodi, Bengaluru 560 030, Karnataka, India. E-mail: drsejian@gmail.com

Author for correspondence
} 
metabolites $(P<0.05)$. Thus, these results indicate that $\mathrm{CG}$ could be used in up to $10 \%$ in replacement of ground corn without significantly affecting the physiological, hematological, and biochemical parameters of the ewes or their reproductive performance before and during the breeding season.

Key words: Estrus. Flushing. Hemogram. Metabolites. Thermoregulation.

\section{Resumo}

Neste estudo, objetivamos avaliar o efeito da suplementação concentrada contendo glicerina bruta (GB) antes e durante a estação de monta sobre as variáveis bioquímicas e fisiológicas, bem como sobre o desempenho reprodutivo das ovelhas Santa Inês. Um total de 24 ovelhas (12 pluríparas e 12 nulíparas, de 4 e 1,5 anos de idade, pesando em média $40 \pm 5$ e $27 \pm 3 \mathrm{~kg}$, respectivamente) foram distribuídas aleatoriamente em três tratamentos constituídos por diferentes concentrações dietéticas de GB $(0,5$ e $10 \%$ da matéria seca total). O experimento durou 63 dias e foi dividido em três fases de 21 dias. Na primeira e segunda fase, os animais foram submetidos ao flushing alimentar. Na segunda e terceira fase, avaliamos o desempenho reprodutivo dos animais. Variáveis climáticas, fisiológicas e bioquímicas sanguíneas também foram estudadas. Os resultados indicaram que a inclusão de GB não influenciou significativamente $(P>0,05)$ no peso corporal das ovelhas nem em seu escore de condição corporal. Todas as ovelhas exibiram estro durante a estação reprodutiva. A frequência respiratória foi significativamente influenciada pela hora do dia $(P<0,0001)$. Uma suplementação com $10 \%$ de GB não alterou drasticamente as variáveis hematológicas e bioquímicas, que estavam dentro do intervalo de referência. No entanto, a semana de suplementação influenciou os metabólitos séricos $(P<0,05)$. Sendo assim, esses resultados indicam que a GB pode ser utilizada em até $10 \%$ na substituição do milho moído, sem afetar significativamente os parâmetros fisiológicos, hematológicos e bioquímicos das ovelhas assim como o desempenho reprodutivo antes e durante a estação de monta.

Palavras-chave: Estro. Flushing. Hemograma. Metabolitos. Termorregulação.

\section{Introduction}

Reproductive functions are impaired by nutritional imbalance during both the pre-pubertal and the active reproductive stage in animals (Kenny \& Byrne, 2018). Therefore, energy supplementation both before and during the breeding season plays a significant role in determining the reproductive efficiency of sheep. However, supplementing conventional feeds has become less frequent mainly owing to the high cost of supplements and the use of alternative feeds (by-products). A variety of alternative feeds that increase the energy supply and lead to improvements in the reproductive and production capacity of the animals have been studied (Lage et al., 2014).

The biodiesel industry is the source of these alternative feeds. This industry has grown rapidly along with the increasing demand for renewable and sustainable energy sources as well as lower power pollution (Popp et al., 2016). Among these by-products, crude glycerin (CG) stands out as an energy source used to replace part of the energy components of the diet. The nutritional value of glycerol makes it suitable for use in ruminant diets, as it acts as a precursor to gluconeogenesis, thus emerging as an alternative feed in sheep diets (Merlim et al., 2015).

Many studies have evaluated the use of $\mathrm{CG}$ in ruminant diets in terms of nitrogen balance (Oliveira et al., 2016), meat quality (Lage et al., 2014), fatty acid profile (Terré, Nudda, Casado, \& Bach, 2011), milk composition (Paiva et al., 2016), and rumen metabolites (Barton et al., 2013); the origin and concentration of glycerol has resulted in different research outcomes. Limited information is available regarding the effects of dietary glycerol as part of flushing (the practice of increasing an animal's nutrient intake and body condition prior to and during breeding in an effort 
to increase its ovulation and fertilization rates) on ewes' performance during the reproductive season. Furthermore, as it is a by-product with high energy density, it can be used to reduce heat production, acting on the adaptive capability of ewes in semiarid regions. Therefore, the present study attempted to generate information about the influence of CG originating from residual frying oils from biodiesel production on the physiology of ewes both before and during the breeding season. Further, we also evaluated the ewes' hematological and biochemical profiles as indicators of metabolic balance as this information will allow us to map the animals' nutritional condition. Additionally, this information will assist in the assessment of the adequacy of nutritional management and the physiological responses of the ewes in terms of the local reality; consequently, this research may lead to the adoption of technologies that will increase the productivity and the reproductive efficiency of the herd.

We hypothesized that $\mathrm{CG}$ with high fat content (264.3 $\mathrm{g} \mathrm{kg}^{-1} \mathrm{DM}$ ) and low glycerol content (306.2 $\mathrm{g} \mathrm{kg}^{-1} \mathrm{DM}$ ) could be used as an energy source in the diet of Santa Inês ewes before and during the breeding season without compromising their adaptive capability, reproductive performance, and productivity. Therefore, the aim of this study was to evaluate the effect of CG supplementation before and during the breeding season on the reproductive, physiological, hematological, and biochemical parameters of Santa Inês ewes.

\section{Materials and Methods}

The experiment was carried out at the DidacticProductive Module of small ruminants of the Technical College of Bom Jesus, Federal University of Piauí, located in Bom Jesus, PI, Brazil (0904'28 "S 4421'31"W).

\section{Animals, experimental diets, and procedures}

Twenty-four Santa Inês ewes (12 pluriparous and 12 nulliparous, $4 \pm 2$ and $1.5 \pm 0.5$ years old, and with an average body weight of $40 \pm 5$ and 27 $\pm 3 \mathrm{~kg}$, respectively), non-pregnant, and clinically healthy, were treated with disophenol $20 \%$ (Ibasa ${ }^{\circledR}$, Porto Alegre, RS, Brazil) to control internal and external parasites and were vaccinated against enterotoxemia.

The study lasted 63 days and was divided into three 21-day phases. In the first and second phases, the ewes were subjected to flushing and in the second and third phases, their reproductive performance was evaluated. Further, in the third phase, all ewes received the same concentrate, i.e., a diet formulation with $0 \% \mathrm{CG}$, as is shown in Figure 1.

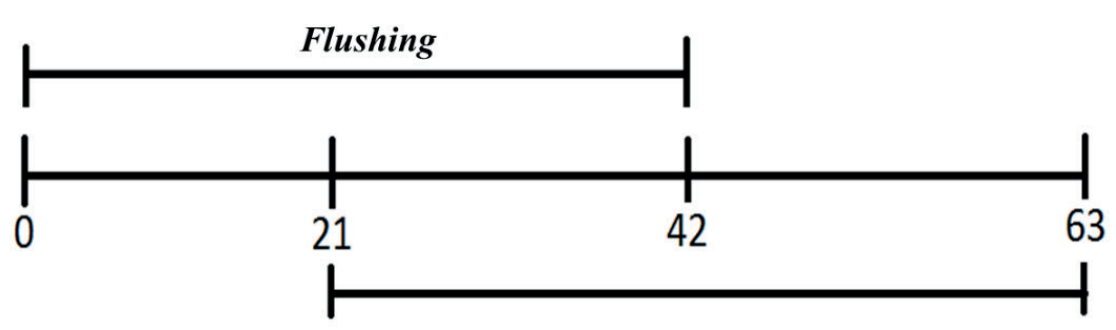

Breeding season

Figure 1. Scheme of feeding and reproductive management during the experimental period. 
With the help of a vasectomized male, the first estrus manifestation was observed from the 22nd until the 63rd day of the experiment. Two daily observations (in the morning and in the afternoon) were performed. The sheep that allowed the vasectomized male to mount them were considered to be in estrus and after $12 \mathrm{~h}$ they were subjected to natural breeding. After coverage, the ewes were reintroduced to the group and were not monitored for estrus thereafter. Thirty days after mating, their pregnancy was confirmed through ultrasonography.
Their prolificacy was calculated by the ratio of the number of lambs born to the number of sheep lambing.

During the experimental period, the ewes remained in a collective stall $(4 \times 10 \mathrm{~m})$, equipped with a feeder and a water fountain. They were fed corn silage and had ad libitum water access. In the late afternoon, the sheep were transferred to individual stalls, where they received concentrate supplementation containing CG, the composition of which is described in Table 1.

Table 1

The ingredients and chemical composition of the concentrate diet

\begin{tabular}{lccc}
\hline \multirow{2}{*}{ Item } & \multicolumn{3}{c}{ Levels of crude glycerin (\% of dry matter) } \\
\cline { 2 - 4 } & 0 & 5 & 10 \\
\hline Ingredient (\% DM) & 75 & 70 & 65 \\
$\quad$ Ground corn & 20 & 19.8 & 19.6 \\
Soybean meal & 0 & 5 & 10 \\
Crude glycerin & 1 & 1 & 1 \\
Limestone & 4 & 4 & 4 \\
Mineral Supplement ${ }^{1}$ & - & 0.2 & 0.4 \\
Urea & & & 85.13 \\
Nutrient (\%DM) & 89.97 & 87.48 & 16.3 \\
$\quad$ Dry matter (g kg ${ }^{-1}$ MN) & 16.15 & 16.23 & 10.76 \\
Crude protein & 12.05 & 11.4 & 6.43 \\
Neutral detergent fiber & 4.3 & 5.36 & 6.38 \\
Ether extract & 6.48 & 6.43 & 60.13 \\
Mineral matter & 61.02 & 60.58 & $610 \mathrm{ng}$ \\
Non-fibrous carbohydrates & $61 \mathrm{~g}$ & & \\
\hline
\end{tabular}

${ }^{1}$ Guarantee levels per kg of product: $267 \mathrm{~g}$ of calcium; $61 \mathrm{~g}$ of phosphorus; $35 \mathrm{~g}$ of sulfur; $20 \mathrm{~g}$ of magnesium; $610 \mathrm{mg}$ of fluorine; $6000 \mathrm{mg}$ of zinc; $350 \mathrm{mg}$ of copper; $23 \mathrm{mg}$ of selenium; $500 \mathrm{mg}$ of molybdenum; $2000 \mathrm{mg}$ of manganese; $60 \mathrm{mg}$ of chromium; 80 $\mathrm{mg}$ of iodine; $20 \mathrm{mg}$ of cobalt e $3000 \mathrm{mg}$ of iron.

CG replaced ground corn for 42 days in and was provided by the Sewage Water Treatment the experimental treatments in the following Agency of the Piauí State (AGESPISA). The CG proportions: $0 \%, 5 \%$, and $10 \%$ of the total dry was manually homogenized and incorporated to matter (DM). The CG (Table 2) used originated the concentrate mixture in the aforementioned from residual frying oils from biodiesel production substitution levels. 
Table 2

Chemical composition of crude glycerin from the biodiesel production from frying oils

\begin{tabular}{|c|c|c|}
\hline Item & ( $\mathrm{g} \mathrm{kg}^{-1}$ Dry matter) & Analytical method \\
\hline Humidity ( $\mathrm{g} \mathrm{kg}^{-1}$ natural matter) & 427.6 & $\begin{array}{l}\text { Association of Official Analytical Chemistis } \\
\text { [AOAC] (1990) - method: } 930.15\end{array}$ \\
\hline Mineral matter & 7.5 & AOAC (1990) - method: 942.05 \\
\hline Crude protein & 9.1 & AOAC (2007) - method: 992.15 \\
\hline Ether extract & 264.3 & AOAC (2007) - method: 920.39 \\
\hline Glycerol & 306.2 & USP (2015) - method: 169 \\
\hline Methanol & 1.11 & USP (2015) - method: 467 \\
\hline Sodium & 1.6 & FDA (2010) - method: 0159 \\
\hline Gross energy (kcal kg ${ }^{-1}$ Dry matter) & 3.787 & bomb calorimeter \\
\hline Total Fatty Acids (g $100^{-1}$ fat) & 29.43 & AOAC (2007) - method: 996.06 \\
\hline
\end{tabular}

During the supplementation period, the body weight of the ewes was measured weekly using a mobile mechanical scale for small ruminants (Balanças Cauduro Ltda. - 499 SU, Cachoeira do Sul, RS, Brazil). Their body condition score (BCS) was determined according to the methodology described by Thompson and Meyer (2006), using a 1-5 scale, where BCS of 1 and 5 represented a thin and a very fat animal, respectively.

\section{Measurement of climatic and physiological variables}

During the experimental period, the climatic variables were monitored continuously using a thermo-hygrometer (temperature and relative humidity, RH), a dry bulb (dry bulb temperature, DBT), a wet bulb (wet bulb temperature), and a black globe (black globe temperature, BGT), which were installed along the animals' height. The black globehumidity index was calculated using the following equation: $\mathrm{BGHI}=\mathrm{BGT}+[0.36 \times \mathrm{DPT}(\mathrm{DBT}-$ $(100-\mathrm{RH} \%) / 5)]+41.5$ described by Buffington, Collazzo-Arocho and Canton (1981), wherein $\mathrm{DPT}=$ dew point temperature. The environmental variables were measured at 07:00 and 15:00 h, three times per week.

The physiological parameters [rectal temperature (RT) and respiratory rate (RR)] were measured three times per week, in the morning (07:00 to 08:00 h) and in the afternoon (15:00 to 16:00 h). To obtain the RT a veterinary clinical thermometer (Incoterm $\AA$, Porto Alegre, Rio Grande do Sul, Brazil) was used; this was introduced into the animal's rectum where it remained for two minutes and the result was expressed in Celsius degrees $\left({ }^{\circ} \mathrm{C}\right)$. The RR (breath/ minute) was measured using a flexible stethoscope at the level of the laryngotracheal region.

\section{Blood sampling}

Blood samples were collected to determine the hematological $(5 \mathrm{~mL})$ and biochemical $(10 \mathrm{~mL})$ profiles of the animals. Blood samples were collected at weekly intervals from all the animals before they set out to graze. Blood samples were collected by jugular venipuncture, using disposable needles (25 $\times 8 \mathrm{~mm}$; Greinerbio-onne ${ }^{\circledR}$, Americana, São Paulo, Brazil) and deposited in vacutainer tubes. The blood samples were collected and kept in two different tubes; one tube contained an anticoagulant agent (ethylenediamine tetraacetic acid) to evaluate the hematological variables, while the other tube did not contain an anticoagulant agent in order to evaluate the biochemical variables. The blood samples were kept in iceboxes until their arrival at the Laboratory of Veterinary Clinical Pathology of the Veterinary Hospital (HVU-CPCE). The biochemical profile samples were centrifuged at $3500 \mathrm{rpm} / 15 \mathrm{~min}$, 
packed as serum aliquots into Eppendorf tubes, and stored in a freezer at $-20{ }^{\circ} \mathrm{C}$ for subsequent analysis. The laboratory analyses were carried out at the Laboratory of Veterinary Clinical Pathology of the University Veterinary Hospital (UFPI-CPCE), located in the city of Bom Jesus, Piauí, Brazil.

\section{Measurement of hematological parameters}

Red blood cell (RBC) and leukocyte (Le) counts were performed in a Neubauer improved cell counting chamber as recommended by Vallada (1999). The hematocrit (Ht) was determined by the microhematocrit technique and the result was expressed as a percentage (\%). Plasma samples were used to measure the total proteins (TP) using a refractometer and analyzed by the degree of light refraction technique (Thrall, Weiser, Campbell, \& Allison, 2015). The cyanmethemoglobin method was used to determine the hemoglobin content, after the samples had been diluted in Drabkin's solution. The values obtained by counting the number of red blood cells and determining the hematocrit and hemoglobin contents were used to establish the values of the absolute hematimetric indexes: mean corpuscular volume (MCV) and mean corpuscular hemoglobin concentration (MCHC). The differential leukocyte count of two blood smears from each sample was measured with the use of Romanowsky-type stains (Panótico Rápido; Laborclin ${ }^{\circledR}$ Ltda, Pinhais, Paraná, Brazil), according to the standard technique for animals described by Viana et al. (2002). In each blood smear, 100 leukocytes were identified, classified according to their morphological and color characteristics, and read in a $1000 \times$ magnification microscope to differentiate among neutrophils, eosinophils, basophils, lymphocytes, and monocytes.

\section{Measurement of biochemical parameters}

The metabolites evaluated were creatinine (Labtest Diagnóstica ${ }^{\circledR}$ S.A, Lagoa Santa, Brazil), urea (urea liquiform; Labtest Diagnóstica ${ }^{\circledR}$ S.A.) by the colorimetric enzymatic method, cholesterol (cholesterol liquiform; Labtest Diagnóstica ${ }^{\circledR}$ S.A.), glucose (glucose liquiform; Labtest Diagnóstica ${ }^{\circledR}$ S.A.), and triglycerides (triglycerides liquiform; Labtest Diagnóstica ${ }^{\circledR} \quad$ S.A.). The enzyme evaluated was aspartate aminotransferase by the UV kinetic method (AST/GOT Liquiform; Labtest Diagnóstica $^{\circledR}$ S.A.). The total protein level was estimated by the biuret method (Labtest Diagnóstica $^{\circledR}$ S.A), while the total serum protein was estimated by the bromocresol green method. All biochemical analyses were performed in a semiautomatic biochemical analyzer $\left(\right.$ Spectrum $^{\circledR}$, São Paulo, Brazil).

\section{Statistical analysis}

The experimental design was completely randomized with measures repeated over time; these measures were three levels of CG inclusion $(0 \%$, $5 \%$, and $10 \%$ of the total dry matter), two parturition orders (PO) (nulliparous and pluriparous), and nine weeks of evaluation. The data were analyzed using the MIXED procedure of SAS (version 9.0) (SAS Inst. Inc., Cary, NC, USA), including in the model the level of CG, PO, and their interactions as fixed effects. Week was considered as a measure repeated in time $($ REPEATED $=$ week $)$. The animal nested within the treatment was considered as a random effect.

In the analysis of the physiological and climatic parameters, the effect of the time of day was considered. Several covariance structures for the residues were compared; among them, the covariance structure of first order autoregression (AR1) was identified as better considering the Bayesian criterion (BIC).

The treatment effects on the analyzed variables were compared by Tukey's adjusted test (option PDIFF ADJUST), being considered significant at $P<$ 0.05 . When the interactions were significant, the F test was conducted using the option SLICE of LSMEANS for the unfolding of the interactions. The residues were plotted against predicted values and were used to verify the assumptions of the homoscedasticity model, which were independence and normality of 
the errors. One data point was considered an outlier and removed from the database when the studentized residual was outside the \pm 2.5 range.

\section{Results and Discussion}

The CG levels did not affect the body weight and BCS of the ewes during the experiment $(P=0.75$ and $P=0.43$, respectively); however, pluriparous ewes had a higher BCS $(P=0.007)$ compared with nulliparous ewes. Further, the effect of the supplementation week on the body weight (BW) $(P$ $=0.001)$ and the $\operatorname{BCS}(P=0.007)$ was verified with a gradual increase of these parameters (Table 3). Although the ewes were in early pregnancy, these values probably resulted from hormonal and uterine changes, such as the progression of pregnancy, the gradual increase of the gravid uterus, the embryonic annexes, and fetal growth (Osol \& Mandala, 2009).

Table 3

Body weight and body condition score of Santa Ines ewes supplemented with crude glycerin before and during breeding season

\begin{tabular}{lcc}
\hline Item & Body weight $(\mathrm{kg})$ & Body condition score \\
\hline Overall average & 39.7 & 2.62 \\
Parturition order & & \\
Nulliparous & $34.27 \mathrm{~b}$ & $2.48 \mathrm{~b}$ \\
Multiparous & $45.17 \mathrm{a}$ & $2.74 \mathrm{a}$ \\
SEM & 2.02 & 0.06 \\
Crude glycerin & & \\
$0 \%$ & 39.80 & 2.53 \\
$5 \%$ & 41.00 & 2.66 \\
$10 \%$ & 38.37 & 2.64 \\
SEM & 2.47 & 0.08 \\
Week of supplementation & & \\
1 & $36.87 \mathrm{~d}$ & $2.41 \mathrm{~d}$ \\
2 & $37.20 \mathrm{~d}$ & $2.50 \mathrm{~cd}$ \\
3 & $37.32 \mathrm{~d}$ & $2.56 \mathrm{bc}$ \\
4 & $37.80 \mathrm{~d}$ & $2.64 \mathrm{ab}$ \\
5 & $39.48 \mathrm{c}$ & $2.62 \mathrm{bc}$ \\
6 & $41.04 \mathrm{~b}$ & $2.66 \mathrm{ab}$ \\
7 & $42.19 \mathrm{a}$ & $2.64 \mathrm{bc}$ \\
8 & $42.00 \mathrm{ab}$ & $2.68 \mathrm{~b}$ \\
9 & $43.59 \mathrm{a}$ & $2.79 \mathrm{a}$ \\
SEM & 1.55 & 0.07 \\
parturition order (PO) & & \\
Level of crude glycerin (CG) & 0.001 & 0.007 \\
Week (S) & 0.75 & 0.43 \\
Interaction & $<0.0001$ & 0.01 \\
\hline & $\mathrm{ns}$ & $\mathrm{Ns}$ \\
\hline
\end{tabular}

Means followed by different letters in the same column differ by Tukey test $(P<0.05)$; SEM $=$ standard error of the mean; ns $=$ not significant. 
The use of flushing in reproductive management aims, indirectly, to increase the BW (by nutrient supplementation) of the ewes for the breeding season, thus improving their BCS and bringing it to levels suitable for reproductive activity in order to increase their ovulation and fertilization rates (Branca, Molle, Sitzia, Decandia, \& Landau, 2000). Flushing also increases the coverage and prolificacy rates owing to the storage of nutrients in the muscular and adipose tissues of the animals, thus being a great reproductive management tool (Kenny \& Byrne, 2018). The established superiority of pluriparous ewes in terms of BW and BCS could be attributed to the fact that these were adult, well-developed females. On the other hand, nulliparous ewes were in constant growth and their organisms required nutrients to support both their development and their pregnancy. In nulliparous sheep and especially those that are raised in pasture-based production systems, the birth of lambs with lower BW, lower milk production, and lambs with delayed growth are common occurrences. The lack of supplementation directly affects both the sheep and the lambs; it also affects the next reproductive cycle by increasing the anestrus period and the lambing interval and by negatively affecting the reproductive performance of ewes. Thus, flushing is recommended not only during but also before the breeding season and during the maternal-dependent phase, aiming for a better development of the animals and positive impacts on their reproductive performance (Torreão et al., 2014).

All ewes exhibited estrus during the breeding season. In the first phase (days $21-41$ ), $83.3 \%$ of the ewes in heat were flushed and $16.7 \%$ were not. In the second phase (days $42-63$ ), $12.5 \%$ of the ewes in heat were flushed and $87.5 \%$ were not (Figure $2)$. There was no treatment effect on either the estrus or the prolificacy percentages. This result may be associated with the fulfillment of the ewes' nutritional requirements as the animals had access to quality roughage (corn silage) as well as mineral supplementation (Table 4).

\section{Table 4}

Identification of estrus and prolificity of Santa Inês sheep supplemented with crude glycerin before and during breeding season

\begin{tabular}{lcc}
\hline Item & Identification of estrus (Days) & Prolificacy (Lambs/ewe) \\
\hline Overall average & 32.12 & 1.33 \\
Parturition order & & \\
Nulliparous & 31.75 & 1.25 \\
Multiparous & 32.50 & 1.42 \\
SEM & 2.08 & 0.14 \\
Crude glycerin & & \\
$0 \%$ & 33.37 & 1.50 \\
$5 \%$ & 27.25 & 1.37 \\
$10 \%$ & 35.75 & 1.12 \\
SEM & 2.55 & 1.17 \\
$P$-value & & \\
Parturition order (PO) & 0.8 & 0.42 \\
Crude glycerin (CG) & 0.08 & 0.33 \\
Interaction $(\mathrm{CG} * \mathrm{PO})$ & $\mathrm{ns}$ & $\mathrm{ns}$ \\
\hline
\end{tabular}

Means followed by different letters in the same column differ by Tukey test $(P<0.05)$; SEM $=$ standard error of the mean; $\mathrm{ns}=$ not significant. 


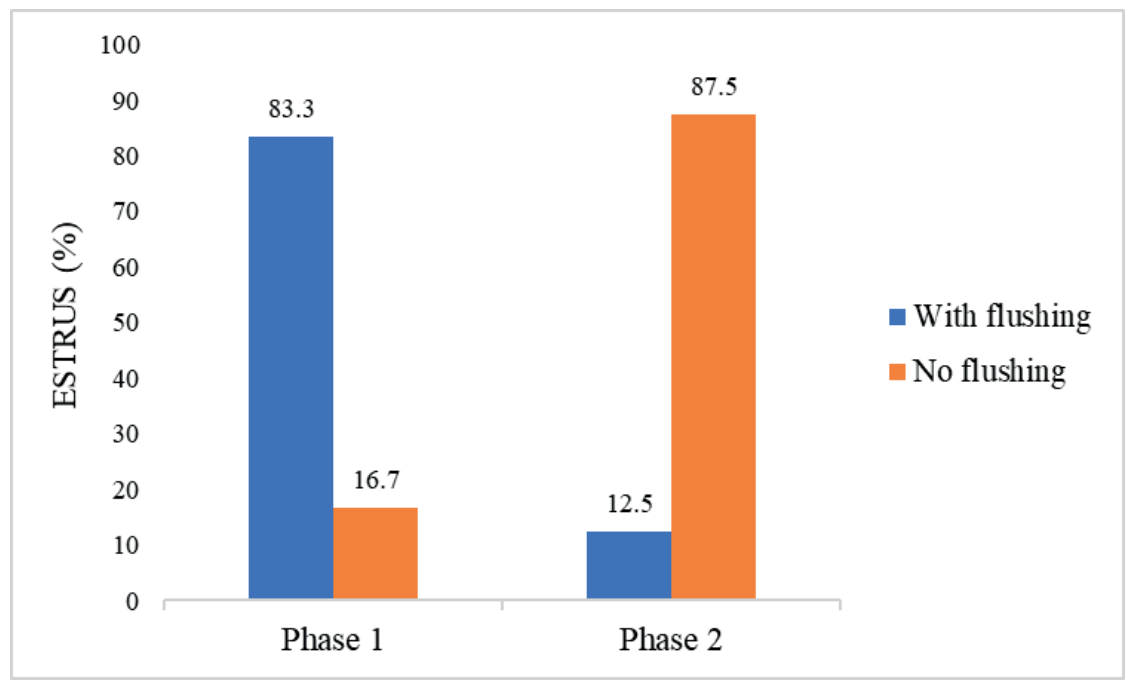

Figure 2. Occurrence of estrus (\%) in Santa Ines ewes supplemented with crude glycerin before and during breeding season (phase $1=21$ to 41 days; phase $2=$ 42 to 63 days).

The thermal comfort zone of sheep is between 20 and $30^{\circ} \mathrm{C}$ (Baêta \& Sousa, 2010). In the current study, the climatic variables studied triggered heat stress during the afternoon thereby initiating the thermoregulatory mechanisms of the animals as reflected by the increase in their RR (Table 5). In optimum temperatures for sheep, $20 \%$ of heat loss occurs through breathing. On the other hand, in temperatures above $35{ }^{\circ} \mathrm{C}$, heat loss via respiration constitutes $60 \%$ of the total heat loss (Sousa et al., 2008).

Table 5

Climatic variables during the experimental period

\begin{tabular}{lcccccc}
\hline Item & $\operatorname{Tmax}\left({ }^{\circ} \mathrm{C}\right)$ & $\mathrm{Tmin}\left({ }^{\circ} \mathrm{C}\right)$ & $\mathrm{RH}(\%)$ & $\mathrm{DBT}\left({ }^{\circ} \mathrm{C}\right)$ & $\mathrm{WBT}\left({ }^{\circ} \mathrm{C}\right)$ & $\mathrm{BGHI}$ \\
\hline Morning $(06: 00-07: 00 \mathrm{~h})$ & $28,07 \mathrm{~b}$ & $26,61 \mathrm{~b}$ & $47,92 \mathrm{a}$ & $27,11 \mathrm{~b}$ & $24,16 \mathrm{~b}$ & $74,24 \mathrm{~b}$ \\
Afternoon $(14: 00-15: 00 \mathrm{~h})$ & $45,28 \mathrm{a}$ & $40,31 \mathrm{a}$ & $25,26 \mathrm{~b}$ & $39,76 \mathrm{a}$ & $30,09 \mathrm{a}$ & $89,22 \mathrm{a}$ \\
SEM & 0,79 & 0,81 & 2,01 & 0,44 & 0,51 & 0,6 \\
$P$-value & & & & & & \\
Period of the day & $<0,0001$ & $<0,0001$ & $<0,0001$ & $<0,0001$ & $<0,0001$ & $<0,0001$ \\
Week & 0,8 & 0,28 & 0,006 & 0,04 & 0,46 & 0,37 \\
Interaction (Period of the day x week) & $\mathrm{ns}$ & $\mathrm{ns}$ & $\mathrm{ns}$ & $\mathrm{ns}$ & $\mathrm{ns}$ & $\mathrm{ns}$ \\
\hline
\end{tabular}

Tmax - maximum temperature; Tmin - minimum temperature; $\mathrm{RH}$ = relative humidity; DBT - dry bulb temperature; WBT - wet bulb temperature; BGHI = black globe-humidity index. Means followed by different letters in the same column differ by Tukey test $(P<0.05) ; \mathrm{SEM}=$ standard error of the mean; $\mathrm{ns}=$ not significant. 
The CG supplementation that aimed to increase the energy density of the diet did not alter the animals' RR and RT. The higher energy density aims to compensate for the lower neutral detergent fiber intake in animals under heat stress and to reduce the impact of heat load from the intake, digestion, and metabolism of nutrients on animal physiology. This process, known as caloric increase, generates heat. In the case of arid and semi-arid regions, thermal stress is considered the most intriguing factor to negatively influence animal production (Pereira et al., 2014; Rocha et al., 2014). Heat stressed animals reduce their caloric intake, thereby reducing their basal heat production, which, consequently, results in the activation of all the physiological variables such as RR, RH, RT. The magnitude of this effect is determined by the environmental and climatic conditions as well as by the physiological, nutritional, and reproductive stages of the animals (Silva et al., 2016). In this context, the adaptive capacity of the breed under study should be considered, as in native breeds, such as Santa Inês, the response to supplementation may not be as pronounced as in exotic breeds.

The time of day affected $(P<0.0001)$ all climatic variables, with higher averages reported in the afternoon, except for the average $\mathrm{RH}$ value, which was higher in the morning (Table 5). The DBT ( $P$ $=0.04)$ and $\mathrm{RH}(P=0.006)$ were influenced by the weeks of evaluation. The BGHI values in the two periods of the day (morning and afternoon) were elevated during the experimental period; however, this was not perceived as a dangerous situation for the ewes, as their RT was within the established average for the species, in a manner characteristic of homeothermic maintenance. The BGHI values were similar to those reported by Silva et al. (2006) and Silva, Souza, Brandão, Marinho and Benício (2011). The RH values were outside the comfort zone of the sheep In the semi-arid region, which has common characteristics with semi-arid tropical environments, the $\mathrm{RH}$ values are outside the comfort zone (50 to $70 \%$ ) of sheep (T. P. D. Silva et al., 2016). In most cases, the adaptive capability of animals was compromised by affecting the most sensible physiological variables such as heart rate and RR. It is important to note that in semiarid regions this impact on animal physiology is prolonged for a large part of the year and affects negatively the reproductive rates and, consequently, the performance of the animals (Wolfenson \& Roth, 2019).

The animals' RR was influenced by the time of day $(P<0.0001)$ with oscillation along the experimental weeks $(P<0.0001)$ (Table 6$)$, probably owing to the daily variation of climatic parameters. In the afternoon, the RR recorded were above the normal values described for sheep (between 16 and 34 breaths/min) (Souza et al., 2008). High temperature, due to the high intensity of solar radiation, was probably responsible for the RR increase in the afternoon as described by Silva et al. $(2013,2016)$. In these cases, the higher the ambient temperature (AT) and the RH variation, the more difficult it will be for the animals to lose heat by non-evaporative mechanisms, such as conduction, convection, and radiation, resulting in heat loss only through evaporative mechanisms culminating in increased RR. The RT was not influenced by the treatments $(P$ $>0.05$ ), being $38.9^{\circ} \mathrm{C}$ on average (Table 6), which is within the normal range for sheep (38.3 to 39.9 ${ }^{\circ} \mathrm{C}$ ) (Ribeiro et al., 2008). It is important to mention that a $1{ }^{\circ} \mathrm{C}$ increase in RT is enough to reduce the performance of most domestic animal species (McDowell, 1972). An RT increase corresponds to heat accumulation in the body caused by the heat from the environment coupled with the internal heat generation during the day and the inability of the thermoregulatory mechanisms to dissipate the excess heat (Baêta \& Sousa, 2010). 
Table 6

Respiratory rate and rectal temperature of Santa Inês ewes supplemented with crude glycerin before and during breeding season

\begin{tabular}{|c|c|c|}
\hline Item & Respiratory rate (breath/min) & Rectal temperature $\left({ }^{\circ} \mathrm{C}\right)$ \\
\hline Overall average & 46.67 & 38.91 \\
\hline \multicolumn{3}{|l|}{ Crude glycerine } \\
\hline $0 \%$ & 45.85 & 38.60 \\
\hline $5 \%$ & 47.08 & 38.61 \\
\hline $10 \%$ & 47.08 & 39.46 \\
\hline SEM & 1.61 & 0.45 \\
\hline \multicolumn{3}{|l|}{ Parturition order } \\
\hline Nulliparous & 45.97 & 38.69 \\
\hline Multiparous & 47.37 & 39.09 \\
\hline SEM & 1.31 & 0.37 \\
\hline \multicolumn{3}{|l|}{ Period of the day } \\
\hline Morning & $31.73 b$ & $38.89 \mathrm{a}$ \\
\hline Afternoon & $61.60 \mathrm{a}$ & $38.88 \mathrm{a}$ \\
\hline SEM & 0.98 & 0.37 \\
\hline \multicolumn{3}{|c|}{ Week of supplementation } \\
\hline 1 & $39.36 \mathrm{e}$ & $38.99 \mathrm{a}$ \\
\hline 2 & $48.66 \mathrm{~b}$ & $38.84 \mathrm{a}$ \\
\hline 3 & $46.59 b$ & $38.60 \mathrm{a}$ \\
\hline 4 & $47.38 b$ & $38.52 \mathrm{a}$ \\
\hline 5 & $57.38^{\mathrm{a}}$ & $38.62 \mathrm{a}$ \\
\hline 6 & $46.22 \mathrm{bc}$ & $38.56 \mathrm{a}$ \\
\hline 7 & $43.75 \mathrm{c}$ & $38.55 \mathrm{a}$ \\
\hline 8 & $42.63 \mathrm{~d}$ & $38.52 \mathrm{a}$ \\
\hline 9 & $48.04 \mathrm{~b}$ & $38.39 \mathrm{a}$ \\
\hline SEM & 1.29 & 0.79 \\
\hline \multicolumn{3}{|l|}{ P-value } \\
\hline Crude glycerin (CG) & 0.82 & 0.33 \\
\hline Period of the day (PD) & $<0.0001$ & 0.98 \\
\hline Parturition order (PO) & 0.46 & 0.46 \\
\hline Week (W) & $<0.0001$ & 0.39 \\
\hline Interaction & $\mathrm{PD} * \mathrm{~W}(<0.0001) ; \mathrm{CG} * \mathrm{~W}(0.01)$ & ns \\
\hline
\end{tabular}

Means followed by different letters in the same column differ by Tukey test $(P<0.05)$; SEM $=$ standard error of the mean; ns = not significant.

The hematological parameters (erythrogram and leukogram) of Santa Inês ewes are shown in Tables $7 \mathrm{a}$ and $7 \mathrm{~b}$. The TP, Ht, and MCV were higher in pluriparous ewes compared with nulliparous ewes. There was an effect $(P<0.05)$ of $\mathrm{CG}$ on $\mathrm{Ht}, \mathrm{MCV}$, leukocytes, neutrophils, and lymphocytes. Despite the effect of different $\mathrm{CG}$ levels on the $\mathrm{Ht}$ and MCV counts, we cannot suggest that this alteration resulted from the use of lipid sources. In ewes supplemented with $10 \%$ CG there was no reduction 
$(P>0.05)$ in TP, RBC, MCHC, and eosinophil counts. Furthermore, it is important to emphasize that all hematological parameters evaluated were within the normal ranges for sheep (Kramer, 2006).
Age was the most likely contributing factor in the increase of the serum parameters of pluriparous ewes (Reece, 1996).

Table $7 \mathbf{a}$

Erythrogram of Santa Ines ewes supplemented with crude glycerin before and during breeding season

\begin{tabular}{|c|c|c|c|c|c|c|c|}
\hline Item & $\begin{array}{c}\mathrm{TP} \\
\left(\mathrm{g} \mathrm{dL}^{-1}\right)\end{array}$ & $\begin{array}{c}\mathrm{RBC} \\
\left(\mathrm{x} 10^{6} \boldsymbol{\mu l}\right)\end{array}$ & $\begin{array}{c}\mathrm{Hb} \\
\left(\mathrm{g} \mathrm{dL}^{-1}\right)\end{array}$ & $\begin{array}{l}\mathrm{Ht} \\
(\%)\end{array}$ & $\begin{array}{l}\mathrm{MCV} \\
(\mathrm{fL})\end{array}$ & $\begin{array}{l}\mathrm{MCHC} \\
\left(\mathrm{g} \mathrm{dL}^{-1}\right)\end{array}$ & $\begin{array}{l}\text { Platelets } \\
\left(\mathrm{x} 10^{3} \boldsymbol{\mu l}\right)\end{array}$ \\
\hline Reference values* & $4-8$ & $8.0-18.0$ & $8-12$ & $22-38$ & $28-40$ & $31-38$ & $300-600$ \\
\hline Overall average & 6.48 & 8.09 & 11.37 & 27.55 & 35.4 & 41.07 & 411 \\
\hline \multicolumn{8}{|l|}{ Parturition order } \\
\hline Nulliparous & $6.23 b$ & $7.92 \mathrm{a}$ & $11.26 \mathrm{a}$ & $26.86 b$ & $34.57 \mathrm{~b}$ & $41.65 \mathrm{a}$ & $406 a$ \\
\hline Multiparous & $6.71 \mathrm{a}$ & $8.20 \mathrm{a}$ & $11.47 \mathrm{a}$ & $28.23 \mathrm{a}$ & $36.23 \mathrm{a}$ & $40.47 \mathrm{a}$ & $416 \mathrm{a}$ \\
\hline SEM & 0.07 & 0.16 & 0.1 & 0.42 & 0.59 & 0.5 & 172 \\
\hline \multicolumn{8}{|l|}{ Crude glycerin } \\
\hline $0 \%$ & $6.58 \mathrm{a}$ & $8.28 \mathrm{a}$ & $11.57 \mathrm{a}$ & $28.31 \mathrm{a}$ & $35.05 b$ & $40.72 \mathrm{a}$ & $419 \mathrm{a}$ \\
\hline $5 \%$ & $6.44 \mathrm{a}$ & $8.14 \mathrm{a}$ & $11.19 \mathrm{a}$ & $26.24 b$ & $33.87 \mathrm{~b}$ & $42.25 \mathrm{a}$ & $437 \mathrm{a}$ \\
\hline $10 \%$ & $6.41 \mathrm{a}$ & $7.76 \mathrm{a}$ & $11.34 \mathrm{a}$ & $28.07 \mathrm{a}$ & $37.28 \mathrm{a}$ & $40.21 \mathrm{a}$ & $377 \mathrm{a}$ \\
\hline SEM & 0.09 & 0.2 & 0.12 & 0.51 & 0.72 & 0.62 & 211 \\
\hline \multicolumn{8}{|c|}{ Week of supplementation } \\
\hline 1 & $6.35 \mathrm{a}$ & $8.14 b$ & $10.98 \mathrm{bc}$ & $25.59 d$ & $31.91 \mathrm{c}$ & $42.63 \mathrm{ab}$ & $400 \mathrm{~b}$ \\
\hline 2 & $6.33 a$ & $7.63 b c$ & $10.98 \mathrm{bc}$ & $26.58 \mathrm{~cd}$ & $35.60 \mathrm{~b}$ & $40.49 \mathrm{ab}$ & $344 b c$ \\
\hline 3 & $6.52 \mathrm{a}$ & $7.36 \mathrm{~b}$ & $10.90 \mathrm{c}$ & $26.11 d$ & $36.33 b$ & $42.25 \mathrm{ab}$ & $376 b$ \\
\hline 4 & $6.63 a$ & $6.50 \mathrm{~d}$ & $11.61 \mathrm{a}$ & $28.91 \mathrm{a}$ & $43.68 \mathrm{a}$ & $40.18 b$ & $412 \mathrm{ab}$ \\
\hline 5 & $6.60 \mathrm{a}$ & $6.57 \mathrm{~d}$ & $11.84 \mathrm{a}$ & $27.81 \mathrm{bc}$ & $43.27 \mathrm{a}$ & $42.81 \mathrm{a}$ & $361 b$ \\
\hline 6 & $6.46 \mathrm{a}$ & $7.24 \mathrm{c}$ & $11.59 \mathrm{a}$ & $27.01 \mathrm{bd}$ & $37.99 b$ & $41.07 \mathrm{ab}$ & $278 \mathrm{c}$ \\
\hline 7 & $6.59 \mathrm{a}$ & $9.51 \mathrm{a}$ & $11.52 \mathrm{ab}$ & $29.06 \mathrm{a}$ & $31.67 \mathrm{c}$ & $39.95 b$ & $524 \mathrm{a}$ \\
\hline 8 & $6.48 \mathrm{a}$ & $9.67 \mathrm{a}$ & $11.47 \mathrm{ac}$ & $28.24 \mathrm{ab}$ & $29.23 c$ & $40.47 \mathrm{ab}$ & $509 \mathrm{a}$ \\
\hline 9 & $6.30 \mathrm{a}$ & $9.93 \mathrm{a}$ & $11.40 \mathrm{ac}$ & $28.56 \mathrm{ab}$ & $28.91 \mathrm{c}$ & $39.70 \mathrm{~b}$ & $494 \mathrm{a}$ \\
\hline SEM & 0.08 & 0.26 & 0.12 & 0.54 & 1.13 & 0.71 & 318 \\
\hline \multicolumn{8}{|l|}{ P-value } \\
\hline Parturition order (PO) & 0.0001 & 0.24 & 0.16 & 0.03 & 0.05 & 0.1 & 0.67 \\
\hline Crude glycerin (CG) & 0.37 & 0.18 & 0.12 & 0.02 & 0.006 & 0.07 & 0.11 \\
\hline Week (W) & 0.8 & $<0.0001$ & $<0.0001$ & $<0.0001$ & $<0.0001$ & $<0.0001$ & $<0.0001$ \\
\hline Interaction & $\begin{array}{l}\mathrm{CG}^{*} \mathrm{~W} \\
(0.007)\end{array}$ & ns & $\begin{array}{c}\mathrm{CG}^{*} \mathrm{~W} \\
(<0.0001)\end{array}$ & ns & ns & $\begin{array}{l}\mathrm{CG}^{*} \mathrm{~S} \\
(0.03)\end{array}$ & ns \\
\hline
\end{tabular}

Means followed by different letters in the same column differ by Tukey test $(P<0.05)$; $\mathrm{SEM}=$ standard error of the mean; ns $=$ not significant; $\mathrm{TP}=$ total Proteins; $\mathrm{RBC}=$ red blood cell $\mathrm{Ht}=$ hematocrit $\mathrm{Hb}=$ hemoglobin; $\mathrm{MCV}=$ mean corpuscular volume; $\mathrm{MCHC}=$ mean corpuscular hemoglobin concentration; * Reference range for sheep (Kramer, 2006). 
Table $7 \mathbf{b}$

Leukogram of Santa Ines ewes supplemented with crude glycerin before and during breeding season

\begin{tabular}{|c|c|c|c|c|c|c|}
\hline Item & $\operatorname{Le}(/ \boldsymbol{\mu l})$ & Ns $(/ \boldsymbol{\mu l})$ & Ly $(/ \boldsymbol{\mu} \mathbf{I})$ & $\operatorname{Eos}(/ \boldsymbol{\mu l})$ & $\operatorname{Bas}(/ \mu \mathrm{l})$ & $\operatorname{Mon}(/ \boldsymbol{\mu l})$ \\
\hline Reference values* & $4000-12000$ & $700-6000$ & $2000-9000$ & $0-1000$ & $0-300$ & $0-750$ \\
\hline Overall average & 5600 & 3046 & 2263 & 216.82 & 11.36 & 64.01 \\
\hline \multicolumn{7}{|l|}{ Parturition order } \\
\hline Nulliparous & $5928 \mathrm{a}$ & $3293 a$ & $2302 a$ & $218.03 a$ & 0 & $55.00 \mathrm{a}$ \\
\hline Multiparous & $5272 b$ & $2800 \mathrm{~b}$ & $2224 a$ & $181.86 \mathrm{a}$ & 53 & $76.43 \mathrm{a}$ \\
\hline SEM & 163 & 114 & 82 & 24.42 & - & 9.4 \\
\hline \multicolumn{7}{|l|}{ Crude glycerin } \\
\hline $0 \%$ & $5744 a$ & $3083 \mathrm{ab}$ & $2392 a$ & $217.82 \mathrm{a}$ & 0 & $65.50 \mathrm{a}$ \\
\hline $5 \%$ & $6119 a$ & $3314 a$ & $2448 \mathrm{a}$ & $290.99 a$ & 0 & $67.00 \mathrm{a}$ \\
\hline $10 \%$ & $4936 b$ & $2742 b$ & $1948 b$ & $172.03 \mathrm{a}$ & 53 & $77.50 \mathrm{a}$ \\
\hline SEM & 200 & 140 & 101 & 29.91 & - & 13.05 \\
\hline \multicolumn{7}{|c|}{ Week of supplementation } \\
\hline 1 & $5900 \mathrm{ab}$ & $3738 \mathrm{a}$ & $1810 \mathrm{c}$ & $108.43 \mathrm{c}$ & 0 & $40.50 \mathrm{a}$ \\
\hline 2 & $5260 \mathrm{~b}$ & $3228 \mathrm{ab}$ & $1861 \mathrm{c}$ & $134.40 \mathrm{c}$ & 0 & $0.00 \mathrm{a}$ \\
\hline 3 & $6020 \mathrm{ab}$ & $3054 \mathrm{ab}$ & $2782 \mathrm{a}$ & $164.92 b c$ & 0 & $76.00 \mathrm{a}$ \\
\hline 4 & $4811 b$ & $2631 b$ & $1903 c$ & $210.17 b$ & 0 & $38.00 \mathrm{a}$ \\
\hline 5 & $4932 b$ & $2646 b$ & $2093 \mathrm{bc}$ & $185.67 b$ & 0 & $92.50 \mathrm{a}$ \\
\hline 6 & $5014 b$ & $2541 b$ & $2077 \mathrm{bc}$ & $226.42 \mathrm{ab}$ & 0 & $66.67 \mathrm{a}$ \\
\hline 7 & $5627 \mathrm{ab}$ & $3096 a b$ & $2316 a b c$ & $303.58 \mathrm{ab}$ & 53 & $63.00 \mathrm{a}$ \\
\hline 8 & $5968 \mathrm{ab}$ & $2830 \mathrm{~b}$ & $2721 \mathrm{ab}$ & $247.93 b$ & 0 & $95.50 \mathrm{a}$ \\
\hline 9 & $6864 a$ & $3652 a$ & $2801 \mathrm{a}$ & $373.21 \mathrm{a}$ & 0 & $82.50 \mathrm{a}$ \\
\hline SEM & 307 & 188 & 157 & 34.97 & - & 15.68 \\
\hline \multicolumn{7}{|l|}{$P$-value } \\
\hline Parturition order (PO) & 0.006 & 0.004 & 0.5 & 0.3 & - & 0.62 \\
\hline Crude glycerin (CG) & 0.0004 & 0.02 & 0.002 & 0.51 & - & 0.89 \\
\hline Week (W) & 0.0003 & $<0.0001$ & $<0.0001$ & $<0.0001$ & - & 0.92 \\
\hline Interaction & $\begin{array}{c}\mathrm{PO} * \mathrm{~W} \\
(0.0002) \\
\end{array}$ & $\begin{array}{l}\mathrm{CG} \times \mathrm{W}(0.004) \\
\mathrm{CG} \times \mathrm{PO}(0.04)\end{array}$ & $\mathrm{T} \times \mathrm{S}(0.01)$ & $\begin{array}{c}\mathrm{CG} \times \mathrm{PO}(0.04) ; \\
\mathrm{CG} \times \mathrm{W}(0.02)\end{array}$ & - & ns \\
\hline
\end{tabular}

Means followed by different letters in the same column differ by Tukey test $(P<0.05)$; SEM $=$ standard error of the mean; ns $=$ not significant; Le $=$ Leukocytes, $\mathrm{Ns}=$ Segmental Neutrophils, Lin= Lymphocytes, Eos $=$ eosinophils, Bas= basophils, Mon= monocytes. *Reference range for sheep (Kramer, 2006).

Regarding the serum biochemical profile, only the cholesterol and urea concentrations were influenced by the CG level; thus, it was evident that the effect of the dietary energy intake was reflected directly in these concentrations, demonstrating that the blood parameters are true indicators of animal health (Table 8). Thus, in the blood level (central compartment of nutrient reserves), nutrients are readily available for metabolism. This compartment is continuously supplied with nutrients by the digestive system, through the dietary supply, organs, and tissues as well as through the kinetics of the elements, i.e., by the nutritional mobilization due to the organism's needs, aiming at homeostasis. This signifies the importance of determining the essential hemato-biochemical parameters for 
health and nutrition assessment and the consequent adequacy of animal management, if necessary. Urea is an indicator of protein metabolism and its concentration in the blood has been used to monitor dietary protein. Again, the age factor is most likely responsible for the differences observed in the blood concentrations of the indicators, as in nulliparous ewes the development process promotes higher protein use metabolism, consequently causing a decrease of nitrogen compounds (Henriques, Gregory, Rizzo, Hasegawa, \& Meira, 2016).

Table 8

Serum biochemical profile $\left(\mathrm{mg} \mathrm{dL}^{-1}\right)$ of Santa Ines ewes supplemented with crude glycerin before and during breeding season

\begin{tabular}{|c|c|c|c|c|c|c|}
\hline Item & Glucose & Triglycerides & Cholesterol & Urea & Creatinine & AST \\
\hline Reference values* & $50-80$ & $\mathrm{set} / 30$ & $52-76$ & $17.12-42.8$ & $1.2-1.9$ & $60-280$ \\
\hline Overall average & 66.9 & 18.9 & 60.2 & 19.12 & 1.2 & 135.78 \\
\hline \multicolumn{7}{|l|}{ Parturition order } \\
\hline Nulliparous & $69.51 \mathrm{a}$ & $19.99 \mathrm{a}$ & $57.50 \mathrm{~b}$ & $17.02 b$ & $1.18 \mathrm{a}$ & $133.95 \mathrm{a}$ \\
\hline Multiparous & $64.43 b$ & $17.87 \mathrm{~b}$ & $62.89 \mathrm{a}$ & $21.22 \mathrm{a}$ & $1.20 \mathrm{a}$ & $137.44 \mathrm{a}$ \\
\hline SEM & 0.88 & 0.44 & 1.7 & 0.7 & 0.02 & 3.43 \\
\hline \multicolumn{7}{|l|}{ Crude glycerine } \\
\hline $0 \%$ & $66.75 \mathrm{a}$ & $18.89 \mathrm{a}$ & $57.47 \mathrm{~b}$ & $19.50 \mathrm{ab}$ & $1.19 \mathrm{a}$ & $140.77 \mathrm{a}$ \\
\hline $5 \%$ & $68.10 \mathrm{a}$ & $19.08 \mathrm{a}$ & $59.30 \mathrm{ab}$ & $17.37 \mathrm{~b}$ & $1.23 \mathrm{a}$ & $132.37 \mathrm{a}$ \\
\hline $10 \%$ & $66.05 \mathrm{a}$ & $18.82 \mathrm{a}$ & $63.81 \mathrm{a}$ & $20.50 \mathrm{a}$ & $1.16 \mathrm{a}$ & $133.95 \mathrm{a}$ \\
\hline SEM & 1.08 & 0.54 & 2.09 & 0.86 & 0.22 & 4.2 \\
\hline \multicolumn{7}{|c|}{ Week of supplementation } \\
\hline 1 & $60.34 \mathrm{e}$ & $20.91 \mathrm{ab}$ & $47.56 \mathrm{~d}$ & $11.94 \mathrm{e}$ & $1.15 \mathrm{a}$ & $130.35 \mathrm{ab}$ \\
\hline 2 & $70.74 b c$ & $18.86 \mathrm{bc}$ & $45.90 \mathrm{~d}$ & $15.79 \mathrm{c}$ & $1.22 \mathrm{a}$ & $136.37 \mathrm{ab}$ \\
\hline 3 & $68.02 \mathrm{c}$ & $17.41 \mathrm{ce}$ & $48.44 d$ & $20.95 b$ & $1.23 \mathrm{a}$ & $140.27 \mathrm{ab}$ \\
\hline 4 & $70.14 b c$ & $15.48 \mathrm{e}$ & $59.46 \mathrm{c}$ & $17.80 \mathrm{~cd}$ & $1.11 \mathrm{a}$ & $138.89 \mathrm{ab}$ \\
\hline 5 & $67.24 \mathrm{~cd}$ & $17.39 \mathrm{ce}$ & $62.53 \mathrm{c}$ & $25.67 \mathrm{a}$ & $1.16 \mathrm{a}$ & $143.69 \mathrm{a}$ \\
\hline 6 & $76.73 \mathrm{a}$ & $19.03 b c$ & $63.19 \mathrm{c}$ & $19.98 \mathrm{~b}$ & $1.23 \mathrm{a}$ & $145.79 \mathrm{a}$ \\
\hline 7 & $52.95 \mathrm{f}$ & $20.00 \mathrm{bc}$ & $69.62 b$ & $24.48 \mathrm{a}$ & $1.19 \mathrm{a}$ & $137.73 \mathrm{ab}$ \\
\hline 8 & $72.75 b$ & $22.80 \mathrm{a}$ & $76.93 a$ & $19.46 \mathrm{bd}$ & $1.20 \mathrm{a}$ & $124.22 b$ \\
\hline 9 & $63.83 \mathrm{de}$ & $18.49 \mathrm{bc}$ & $68.09 \mathrm{~b}$ & $16.03 \mathrm{c}$ & $1.23 \mathrm{a}$ & $123.95 b$ \\
\hline SEM & 1.35 & 0.67 & 2.02 & 0.93 & 0.03 & 4.13 \\
\hline \multicolumn{7}{|l|}{ P-value } \\
\hline Parturition order $(\mathrm{PO})$ & 0.0002 & 0.002 & 0.03 & 0.0002 & 0.32 & 0.47 \\
\hline Crude glycerin (CG) & 0.4 & 0.94 & 0.04 & 0.04 & 0.07 & 0.34 \\
\hline Week (W) & $<0.0001$ & $<0.0001$ & $<0.0001$ & $<0.0001$ & 0.07 & 0.0001 \\
\hline Interaction & ns & $\begin{array}{c}\mathrm{CG}^{*} \mathrm{~W} \\
(0.0001)\end{array}$ & ns & $\begin{array}{l}\mathrm{CG}^{*} \mathrm{~W} \\
(0.03)\end{array}$ & $\begin{array}{l}\mathrm{CG}^{*} \mathrm{~W} \\
(0.02)\end{array}$ & $\begin{array}{c}\mathrm{CG}^{*} \mathrm{PO} \\
(0.04)\end{array}$ \\
\hline
\end{tabular}

Means followed by different letters in the same column differ by Tukey test $(P<0.05)$; SEM $=$ standard error of the mean; ns = not significant; *Kaneko, Harvey and Bruss (2008). 
Added ingredients in supplements with high lipid content and their influence on the energy metabolism of ruminants have been evaluated in terms of the lipid profile (Fernandes et al., 2012). In this context, serum triglyceride levels in ruminants are low compared with non-ruminants, reflecting their low hepatic synthesis capacity (Fernandes et al., 2012). The cholesterol concentration reflects the energy metabolism in the liver, particularly the export of lipids in the form of Very low density lipoproteins (Ndlovu et al., 2007). The decrease in serum cholesterol levels in this study indicates an energy deficit, while increases occur in response to the ingestion of high energy foods in the form of lipids (Fernandes et al., 2012). In the present study, the serum triglyceride levels were not altered as a result of the diet; however, ewes fed $5 \%$ and $10 \%$ of CG had increased cholesterol. In nulliparous ewes, higher triglyceride concentrations were established, probably owing to the increase of glucose and its conversion (excess) to lipids. Pluriparous ewes, on the other hand, had higher serum cholesterol, owing to the higher energy intake that caused high lipid deposition; this can be justified by the pluriparous ewes' larger size and body weight and higher BCS. However, it should be emphasized that the values obtained are within the species' normal range (Kaneko et al., 2008).

The variation of serum metabolites throughout the weeks of supplementation had a direct effect on the reproductive performance of sheep. This was in agreement with the findings reported in sheep by Viñoles et al. (2005). The effect of shortterm nutritional supplementation on the follicular development of ewes may have occurred due to the increase in plasma glucose concentrations acting directly on the ovaries. The stage of follicular development under maximum glucose and metabolic hormone concentrations may be the determining factor for the increase in the ovulation rate of ewes.

\section{Conclusions}

CG with high fat and low glycerol content can substitute ground corn up to $10 \%$ in Santa Inês ewes' diet before and during the breeding season without causing significant changes on their physiological and hematological variables and while preserving their reproductive performance.

\section{Conflict of interest}

The authors declare that they have no conflict of interest.

\section{Approval of the Bioethics and Biosafety Committee}

This study complied with all ethical principles in research involving animals and it was approved by the Bioethics Committee of the UFPI (PROPESQUFPI-047/2013) and the Ethics Committee on Animal Use (Protocol ID: 016/14).

\section{References}

Association of Official Analytical Chemistis (1990). Official Methods of Analysis (15nd ed.). Arlington, VA: Association of Official Analytical Chemists.

Association of Official Analytical Chemistis (2007). Official Methods of Analysis of Official Analytical Chemists International (20nd ed.). Arlington: VA: Association of Official Analytical Chemists.

Baêta, F. C., \& Souza, C. F. (2010). Ambiência em edificações rurais - conforto animal (2a ed.). Viçosa, MG: UFV.

Barton, L., Bures, D., Homolka, P., Jancík, F., Marounek, M., \& Rehák, D. (2013). Effects of longterm feeding of crude glycerine on performance, carcass traits, meat quality, and blood and rumen metabolites of finishing bulls. Livestock Science, 155(1), 53-59. doi: 10.1016/j.livsci.2013.04.010

Branca, A., Molle, G., Sitzia, M., Decandia, M., \& Landau, S. (2000). Short-term dietary effects on reproductive wastage after induced ovulation and artificial insemination in primiparous lactating Sarda ewes. Animal Reproduction Science, 58(2), 59-71. doi: 10.1016/s0378-4320(99)00079-2 
Buffington, D. E., Collazzo-Arocho, A., \& Canton, G. H. (1981). Black globe-humidity índex (BGHI) as confort equation for dairy cows. Transaction of the ASAE, 24(3), 711-714. doi: 10.13031/2013.34325

Fernandes, S. R., Freitas, J. A., Souza, D. F., Kowalski, L. H., Dittrich, R. L., Rossi, P., Jr., \& Silva, C. J. A. (2012). Lipidograma como ferramenta na avaliação do metabolismo energético em ruminantes. Revista Brasileira de Agrociência, 8(1),1-32. doi: 10.18539/ CAST.V18I1.2484

FDA (2010). Food and drug administration. Elemental analysis manual. United States of America. Section 4.4 Inductively Coupled Plasma - Atomic Emission Spectrometric Determination of Elements in Food Using Microwave Assisted Digestion.

Henriques, L. C. S., Gregory, L., Rizzo, H., Hasegawa, M. Y., \& Meira, E. B. S., Jr., (2016). Avaliação dos fatores etários sobre a função renal de ovelhas Santa Inês. Pesquisa Veterinária Brasileira, 36(7), 642646. doi: 10.1590/S0100-736X2016000700014

Kaneko, J. J., Harvey, J. W., \& Bruss, M. L. (2008). Clinical biochemistry of domestic animal (6nd ed.). San Diego: Academic Press.

Kenny, D. A., \& Byrne, C. J. (2018). Review: the effect of nutrition on timing of pubertal onset and subsequent fertility in the bull. Animal, 12(S1), 3644. doi: $10.1017 / \mathrm{S} 1751731118000514$

Kramer, J. W. (2006). Normal hematology of cattle, sheep, and goats, In: B. F., Feldman, J. G. Zinkl, \& N. C Jain (Eds.), Schalm's Veterinary Hematology (5th ed., p. 1075-1084). Williams and Wilkins, Lippincott.

Lage, J. F., Ribeiro, A. F., San Vito, E., Delevatti, L. M., Dallanttonia, E. E., Baldi, F., \& Reis, R. A. (2014). Ruminal fermentation of steers fed crude glycerin replacing starch-vs fiber-based energy ingredients at low or high concentrate diets. Acta Scientiarum. Animal Sciences, 39(1), 57-64. doi: 10.4025/ actascianimsci.v39i1.32895

Mcdowell, R. E. (1972). Improvement of livestock production in warm climates. Improvement of livestock production in warm climates. San Francisco: W. H. Freeman.

Merlim, A., Silva, A. G., Sobrinho, Cirne, L. G. A., Romanzini, E. P., Andrade, N., \& Almeida, F. A. (2015). Ile De France Lambs Fed Diets Containing Glycerin: Characteristics of Carcass and Commercial Cuts. Journal of Agricultural Engineering and Biotechnology, 3(2), 79-83. doi: 10.18005/ JAEB0302005
Ndlovu, T., Chimonyo, M., Okoh, A. I., Muchenje, V., Dzama, K., \& Raats, J. G. (2007). Assessing the nutritional status of beef cattle: current practices and future prospects. African Journal of Biotechnology, 6(24), 2727-2734. doi: 10.5897/AJB2007.000-2436

Oliveira, C. A. A., Filho, Azevedo, J. A. G., Carvalho, G. G. P., Reis, L. G., Almeida, F. M., \& Souza, L. L. (2016). Crude glycerin combined with sugar cane silage in lamb diets. Tropical Animal Health and Production, 48(2), 289-295 doi: 10.1007/s11250015-0948-7

Osol, G., \& Mandala, M. (2009). Maternal uterine vascular remodeling during pregnancy. Physiology, 24(2), 58-71. doi: 10.1152/physiol.00033.2008

Paiva, P. G., Del Valle, T. A., Almeida, G. F., Bueno, I. C. S., Bradford, B. J., \& Rennó, F. P. (2016). Effects of crude glycerin on milk composition, nutrient digestibility and ruminal fermentation of dairy cows fed corn silage-based diets. Animal Feed Science and Technology, 212(3), 136-142. doi: 10.1016/j. anifeedsci.2015.12.016

Pereira, A. M., Silva, T. P. D., Sousa, K. R. S., Gottardi, F. P., Marques, C. A. T., \& Torreão, J. N. C. T. (2014). Thermoregulatory traits of native sheep in pregnancy and supplemented in grazing system. Journal of Agricultural Science, 6(9), 113-119. doi: 10.5539/ jas.v6n9p113

Popp, J., Harangi-Rákos, M., Gabnai, Z., Balogh, P., Antal, G., \& Bai, A. (2016). Biofuels and their coproducts as livestock feed: global economic and environmental implications. Molecules, 21(3), 285. doi: 10.3390/molecules21030285

Reece, W. O. (1996). Fisiologia de animais domésticos. São Paulo: Roca.

Ribeiro, L. R., Damasceno, J. C., Jobim, C. C., Santos, G. T., Macedo, F. A. F., \& Macedo, L. G. P. (2008). Produção, composição do leite e constituintes sanguíneos de cabras alimentadas com diferentes volumosos. Arquivo Brasileiro de Medicina Veterinária e Zootecnia, 60(6), 1523-1530. doi: 10.1590/S0102-09352008000600032

Rocha, R. R., Santos, P. B., Nunes, A. G., Silva, T. P. D., Pereira, A. M., \& Torreão, J. N. C. (2014). Adaptive parameters and thermal comfort of postpartum ewes fed on concentrate supplementation in grazing system. Acta Scientiarum. Animal Science, 36(3), 317-321. doi: 10.4025/actascianimsci. v36i3.22823

Silva, C. M. B. A., Souza, B. B., Brandão, P. A., Marinho, P. V. T., \& Benício, T. N. A. (2011). Efeito das condições climáticas do semiárido sobre $\mathrm{O}$ 
comportamento fisiológico de caprinos mestiços F1 Saanen x Boer. Revista Caatinga, 24(4), 195-199.

Silva, E. M. N., Souza, B. B., Cezar, M. F., Souza, W. H., Benicio, T. M. A., \& Freitas, M. M. S. (2006). Avaliação da adaptabilidade de caprinos exóticos e nativos no semi-árido paraibano. Ciência $e$ Agrotecnologia, 30(3), 516-521. doi: 10.1590/ S1413-70542006000300018.

Silva, T. P. D., Sousa, S. C., Jr., Santos, K. R., Marques, C. A. T., \& Torreão, J. N. C. (2013). Características termorreguladoras e ganho de peso de cordeiros Santa Inês no sul do estado do Piauí no período de transição seca/águas. Agrarian, 6(20), 198-204.

Silva, T. P. D., Torreão, J. N. C., Marques, C. A. T., Araújo, M. J., Dhanasekaran, D. K., \& Sejian, V. (2016). Effect of multiple stress factors (thermal, nutritional and pregnancy type) on adaptive capability of native ewes under semi-arid environment. Journal of Thermal Biology, 59(7), 39-46. doi: 10.1016/j. jtherbio.2016.05.001

Sousa, S. C., Jr., Morais, D. E. F., Vasconcelos, A. M., Nery, K. M., Morais, J. H. G., \& Guilhermino, M. M. (2008). Características termorreguladoras de caprinos, ovinos e bovinos em diferentes épocas do ano em região semi-árida. Revista Científica de Produção Animal, 10(2), 127-137. doi: 10.15528/466

Souza, B. B., Souza, E. D., Cezar, M. F., Souza, W. H., Santos, J. R. S., \& Benício, T. M. A. (2008). Temperatura superficial e índice de tolerância ao calor de caprinos de diferentes grupos raciais no semiárido nordestino. Ciência e Agrotecnologia, 32(1), 275-280. doi: 10.1590/S1413-70542008000100039.

Terré, M., Nudda, A., Casado, P., \& Bach, A. (2011). The use of glycerin in rations for light lamb during the fattening period. Animal Feed Science and Technology, 164(4), 262-267. doi: 10.1016/j. anifeedsci. 2010.12.008
Thompson, J., \& Meyer, H. (2006). Body condition scoring of sheep. In Biennial spooner sheep day. Proceedings. Madison, Wisconsin: University of Wisconsin, 52.

Thrall, M. A., Weiser, G., Campbell, T. W., \& Allison, T. W. (2015). Hematologia e bioquímica clínica veterinária ( $2 \mathrm{a}$ ed.). Rio de Janeiro: Guanabara Koogan.

Torreão, J. N. C., Rocha, A. M., Marques, C. A. T., Bezerra, L. R., Gottardi, F. P., \& Oliveira, R. L. (2014). Concentrate supplementation during pregnancy and lactation of ewes affects the growth rate of lambs from a variety of crosses. Revista Brasileira de Zootecnia, 43(4), 544-550. doi: 10.1590/S1516-35982014001000006

USP (2015). United States Pharmacopeial Convention. The official compendia of standards, (38th ed.). Rockville.

Vallada, E. P. (1999). Manual de técnicas hematológicas. São Paulo: Atheneu.

Viana, R. B., Birgel, E. H., Jr., Ayres, M. C. C., Biojoni, F. S. M., Souza, M. C. C., \& Birgel, E. H. (2002). Influência da gestação e do puerpério sobre o leucograma de caprinos da raça Saanen, criados no Estado de São Paulo. Brazilian Journal Veterinary Research Animal Science, 39(3), 196-200. doi: 10.1590/S1413-95962002000400006

Viñoles, C., Forsberg, M., Martin, G. B., Cajarville, C., Repetto, J., \& Meikle, A. (2005). Short term nutritional supplementation of ewes in low body conditions affects follicle development due to an increase in glucose and metabolic hormones. Reproduction, 129(6), 299-309. doi: 10.1530/ rep. 1.00536

Wolfenson, D., \& Roth, Z. (2019). Impact of heat stress on cow reproduction and fertility. Animal Frontiers, 9(1), 32-38. doi: 10.1093/af/vfy027 
